\title{
THO Complex Subunit 5 Homolog
}

National Cancer Institute

\section{Source}

National Cancer Institute. THO Complex Subunit 5 Homolog. NCI Thesaurus. Code C21515.

THO complex subunit 5 homolog ( $683 \mathrm{aa}, \sim 79 \mathrm{kDa}$ ) is encoded by the human THOC5 gene. This protein plays a role in cell differentiation and mRNA splicing. 